\title{
Communication
}

[Comunicação]

\section{Corallus caninus (Serpentes, Boidae): a new host for Ophiotaenia sp. (Cestoda, Proteocephalidae)}

[Corallus caninus (Serpente, Boidae): novo hospedeiro de Ophiotaenia sp. (Cestoda, Proteocephalidae]

\author{
R.J. Silva ${ }^{1}$, R.C. Portela ${ }^{2}$, F.J.M. Santos ${ }^{3}$ \\ ${ }^{1}$ Departamento de Parasitologia-Instituto de Biociências - UNESP \\ Distrito de Rubião Júnior, $\mathrm{s} / \mathrm{n}^{\circ}$ \\ 18618-000 - Botucatu, SP \\ ${ }^{2}$ Parque Zoológico de Goiânia - Goiânia, GO \\ ${ }^{3}$ Aluno de graduação - PUC-Goiás - Goiânia, GO
}

Taxonomic studies on the Ophiotaenia genus have showed that there are more than 70 species reported in the world. Six species of this genus have been recorded in Brazil. Five of them are snake parasites $(O$. calmetti, O. elongata, $O$. flava, O. hyalina, and O. macrobothria) and another $(O$. lopesi) is a lizard parasite (Schmidt, 1986). Ophiotaenia jarara was reported in Bothrops alternatus (Fuhrmann, 1927) and B. jararaca (Santos and Tayt-Son Rolas, 1973) but it was reviewed and renamed as Proteocephalus jarara (Chambrier et al., 1991). Santos and TaytSon Rolas (1973) also recorded a specimen of Ophiotaenia sp. from B. jararaca, however these authors could not identify the species.

Only a few Brazilian snakes have been reported as host for Ophiotaenia spp., among them, $B$. jararaca (= Lachesis lanceolatus), B. atrox, Coluber sp., and Micrurus corallinus (= Elaps corallinus). The aim of this paper is to report the first occurrence of Ophiotaenia sp. in a specimen of C. caninus (Serpentes, Boidae) in Brazil.

The snake was apprehended with an animal trafficker in Goiânia, Goiás State, Brazil, and was maintained at the Goiânia Zoo. The animal was apathetic, with disecdysis and dehydration. After some days, it died in captivity. The necropsy revealed one tapeworm in its intestine (Fig. 1). The tapeworm was collected, fixed with AFA solution after flattening, stained with carmine, cleared in creosote, and mounted in Permount resin. A morphological evaluation was performed using a computerized system for image analysis ${ }^{1}$.

The observed morphologic characteristics were the following: unarmed scolex, with four suckers, $241 \mu \mathrm{m}$ diameter; short neck, 9340 $\mu \mathrm{m}$ long; strobile acraspedote; imature proglottids $182 \mu \mathrm{m}$ long and $366 \mu \mathrm{m}$ wide; mature proglotidds $1626 \mu \mathrm{m}$ long and $2144 \mu \mathrm{m}$ wide; gravid proglottids $7487 \mu \mathrm{m}$ long and $2161 \mu \mathrm{m}$ wide; genital pore irregularly distributed, opening in the middle of the proglottids; vagina anterior or posterior to the cirrus pouch; cirrus pouch $461 \mu \mathrm{m}$ long and $191 \mu \mathrm{m}$ wide; testicle in two separated fields; ovary $1633 \mu \mathrm{m}$ wide and area of $171 \mathrm{~mm}^{2}$; vitellines distributed as a lateral line, $78 \mu \mathrm{m}$ wide; uterus with numerous lateral diverticules.

The morphologic and morphometric data allowed to conclude that the tapeworm involved in the parasitism was a species of the genus Ophiotaenia. However, the obtained data showed that this cestode is different from the five species previously described in Brazilian snakes (Schmidt, 1986). 

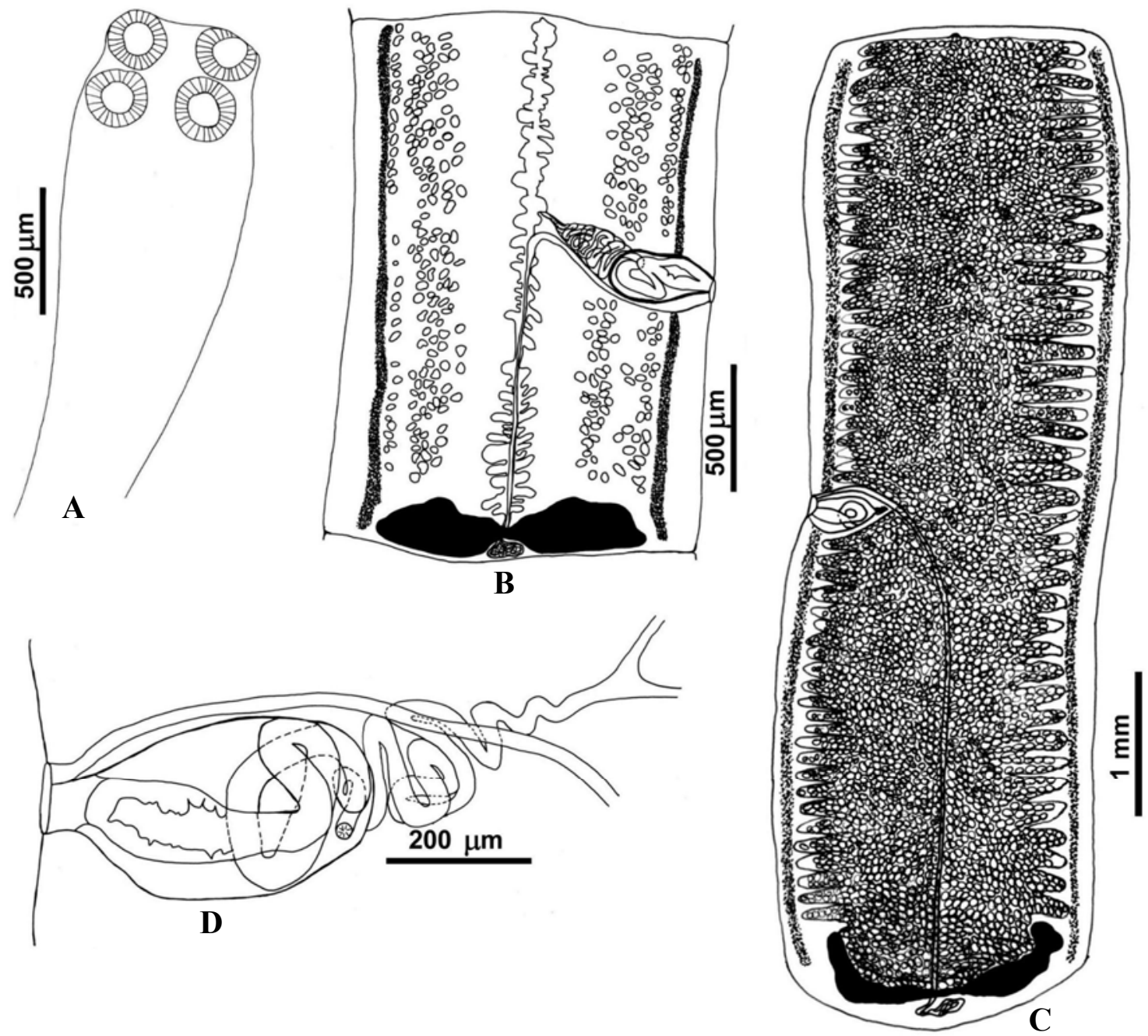

Figure 1. Ophiotaenia sp. (Cestoda, Proteocephalidae) found in the intestine of a Corallus caninus (Serpentes, Boidae) snake. A) scolex, B) mature proglottid, C) gravid proglottid, and D) detail of the cirrus pouch and vagina.

The genus Ophiotaenia has not been well studied in Brazil and its taxonomy is complex. It was not possible to identify Ophiotaenia species due to the lack of material to compare to other specimen. Thus, the voucher cestode was deposited in the helminthological collection of the "Instituto de Biociências, Unesp, Botucatu", under the registration number of CHIBBUNESP-484, for future taxonomic studies.
However, the publication of this case is important because this is the first report on the occurrence of a cestode of the genus Ophiotaenia infecting $C$. caninus.

Keywords: Ophiotaenia sp., Proteocephalidae, cestoda, Corallus caninus

\section{RESUMO}

Relata-se a ocorrência de Ophiotaenia sp. (Cestoda, Proteocephalidae) parasitando Corallus caninus (Serpentes, Boidae). A serpente foi recebida no Parque Zoológico de Goiânia, Goiás, proveniente de apreensão pelo RAN/IBAMA em tráfico de animais silvestres. O animal estava apático, com disecdise e 
desidratação. Após alguns dias, morreu no cativeiro. A necropsia revelou a presença de um cestódeo no intestino que foi fixado em AFA após compressão, corado em carmim e analisado em sistema de análise de imagens. Os aspectos morfológicos indicaram ser uma espécie do gênero Ophiotaenia, mas não foi possivel sua identificação. Este é o primeiro relato sobre a ocorrência de um cestódeo do gênero Ophiotaenia parasitando C. caninus.

Palavra-chave: Ophiotaenia sp, Proteocephalidae, Cestoda, Corallus caninus.

\section{REFERENCES}

CHAMBRIER, A.; D'ALESSIO, M.L.; CORRÊA, F.M. Redescription de Proteocephalus jarara (Fuhrmann, 1927) (Cestoda: Proteocephalidae) parasite de Bothrops alternatus (Viperidae) au Brésil. Rev. Suisse Zool., v.98, p.15-32, 1991.

FUHRMANN, O. Brasilianische cestoden aus reptilien und vogeln. Abn. Senckenb. Naturforsch. Ges., v.40, p.389-401, 1927.
SANTOS J.C.; TAYT-SON ROLAS, F.J. Sobre alguns cestóides de Bothrops e de Liophis miliaris. Atas Soc. Biol. RJ, v.17, p.35-40, 1973.

SCMIDT, G.D. Handbook of tapeworm identification. Florida: CRC, 1986. 675p. 